\title{
ALI JUM'AH SUFISTIC THINKING AND ITS RELEVANCE ON ISLAMIC EDUCATION (PAI) IN HIGHER EDUCATION
}

\author{
Fahrudin', M. Abdul Somad², Risris Hari Nugraha3 , Muhamad Parhan4, \\ Mohammad Rindu Fajar Islamy ${ }^{\mathbf{5}}$ \\ 1,2,3,4,5Universitas Pendidikan Indonesia \\ 1,2,3,4,5Jalan dr. Setiabudi No. 229, Isola, Kota Bandung, Jawa Barat \\ Email: fahrudins59@upi.edu' ${ }^{1}$,somad100@upi.edu², risrisharinugraha@upi.edu ${ }^{3}$, \\ parhan.muhamad@upi.edu ${ }^{4}$, fajarislam2000@upi.edu ${ }^{5}$
}

\begin{abstract}
:
Strengthening spiritual values through the dimensions of tasawwuf learning is one of the efforts to improve changes in students' moral mentality. Sheikh Ali Jum'ah as a charismatic cleric at Al-Azhar University and a former Mufi of Egypt, one of the international scholars who payed attention to the discourse, according to him, instilling modern Sufistic values of Sufism in the young generation can be a supporter of forming a young age who is religious and has good intellect. This article aims to examine and explore the Sufistic concept of Alī Jum'ah to increase individual piety and discuss the relevance of its Sufistic theory to the learning of Islamic Religious Education in Higher Education. Using a literature review approach, his works are collected from various sources and studied interactively through the Islamic studies approach. The primary reference source is his work entitled At-Tharīq Ilā Allah, while the second reference refers to other books. The Sufistic concept of Ali Jum'ah is built on six main principles where the axis is Allah Al-Makshd Al-Kulli. At the practical level, repentance, tafakkur, tadabbur, and consistency in dhikr are the primary tools for ma'rifatullah. Manhaj, the existence of a Murshid and a Salik are the essential pillars in the world of Sufism. Its sufistic relevances in PAI learning which substantially impacts on strengthening the five main components, namely learning objectives, learning materials, learning approaches, lecturers, and students in higher education.
\end{abstract}

\begin{abstract}
Abstrak:
Memperkuat nilai-nilai spiritualitas melalui dimensi pembelajaran tasawwuf merupakan salah satu upaya untuk memperbaiki perubahan mentalitas akhlak pada siswa. Syeikh Ali Jum'ah sebagai ulama kharismatik Universitas Al-Azhar dan manfat Mufi Mesir salah satu ulama internasional yang menaruh perhatian terhadap diskurus tersebut dimana menurutnya menanamkan nilai-nilai sufistik tasawwuf modern terhadap generasi muda dapat menjadi penyokong membentuk generasi muda yang religius serta memiliki intelektualitas baik. Artikel ini bertujuan untuk menelaah serta menjelajahi konsep sufistik Alī Jum'ah dalam rangka meningkatkan kesalehan individu serta mengkaji relevansi teori sufistiknya terhadap pembelajaran Pendidikan Agama Islam di Perguruan Tinggi. Dengan menggunakan pendekatan literature review, karya-karya beliau dikumpulkan dari berbagai sumber serta dianalisis secara interaktif melalui pendekatan Islamic studies. Sumber rujukan primer diambil dari karyanya berjudul At-Tharīq Ilā Allah sedangkan rujukan sekunder merujuk kepada kitab-kitab yang lainnya. Konsep Sufistik Alī Jum'ah dibangun atas enam kaidah utama dimana porosnya adalah Allah Al-Makshūd Al-Kulli. Tataran praktisnya, aktivitas taubat, tafakkur, tadabbur, dan konsistensi dalam dzikir menjadi alat utama menuju ma'rifatullah. Manhaj, keberadaan Mursyid dan Seorang Salik merupakan rukunrukun esensial dalam dunia tasawwuf. Relevansi sufistiknya dalam pembelajaran PAI
\end{abstract}


berdampak kuat terhadap penguatan empat komponen utama yaitu tujuan pembelajaran, metode pembelajaran, dosen, serta mahasiswa di perguruan tinggi.

\section{Keywords:}

Sufi, Alī Jum'ah, Religiosity, PAI, Implications, Higher Education

How to Cite: Fahrudin, Somad, M. A., Nugraha, R. H., Parhan, M., \& Islamy, M. R. F. (2021). Ali Jumah Sufistic Thinking and Its Relevance on Islamic Education (PAI) in Higher Education. Lentera Pendidikan : Jurnal Ilmu Tarbiyah dan Keguruan, 24(2), 238-254. https://doi.org/10.24252/lp.2021v24n2i7.

\section{INTRODUCTION}

The world of education is currently faced with various kinds of challenges that are so complex and diverse, one of which is the changing conditions of the world towards globalization. Globalization emerged as a new social, political, and economic force by challenging national boundaries, norms, and cultural behaviors worldwide (Weldon, Rexhepi, Chang, Jones, \& Layton, 2011). From a historical perspective, intellectuals see that this current turned into a substantial transformation with a long process, although in these two decades, the effect was significant. The world's scholars are anxious about its impact, and of course, it encourages them to conduct more in-depth research on this discourse. The international intellectual Rawashdeh researched the effect of globalization on Saudi Arabia's youth political culture millennials (Al-Rawashdeh, 2014). The Chinese intellectual Wing Wah Law has proven that globalization has suppressed value education to resolve the apparent contradiction between national identity and national unity in China's ever-changing game of history and politics. (Law \& Ho, 2009). In the economic aspect, Korean intellectual Jai Mah revealed the lousy impact caused by the current globalization on the inequality of economic opinion in Korea (Mah, 2002). In line with Jai Mah, Jonathan London concluded from his research analysis that the results show that successive waves of globalization have affected education governance in Vietnam differently (London, 2010). In Jamaica, Kinkead-Clark found strong evidence of globalization's impact on children's education (Kinkead-Clark, 2017).

In the academic world in higher education, as stated by Severino Macingambi, several well-known thinkers assess that globalization tends to change the education system from public services to commercial commodities that are sold for large profits with the end that students from lower social classes will not want to buy it (Machingambi, 2014). In addition, globalization reduces values and ethos in the higher education system, leading to increased educational inequality and social disharmony. In several European countries such as Belgium, Canada, the United Kingdom, and the United States, higher education in tertiary institutions still maintains its distinctive character while reviewing the opportunities offered by globalization and internationalization (Tight, 2021). Robert Burner is even concerned about the impact, namely the large gap between what the world needs and what management practitioners generally do in the world of education (Bruner \& Iannarelli, 2011). In dealing with the dimensions of globalization, Lin Goodwin offers an 
alternative concept of what teachers should have today, which according to him, teachers must have at least four sizes: curricular, professional, good moral, and good personality (Goodwin, 2020).

Al-Quran is a guide and way of life that must be actualized in social life (Al-Qardhawi, 1996, 2007). The instilling of spiritual values has been conditioned by the Prophet Muhammad to his companions as a part of an effort to realize a religious value of Islam called rahmatan lil alamin (As-Shalabi, 2008; Ghadhban, 1992; Islamy, Supriadi, Rojak, Romli, Anwar, \& Parhan, 2020; Rawwas, 1988). Character education based on the teachings of Islam is the main focus for Indonesian Muslim scholars (Mucharomah, 2017; Nugroho, 2017; Sajadi, 2019; Zulfa, 2018). An international study developed by Rashaun Black published in the Journal of Memory showed a significant improvement in a person's intelligence and long-term memory (Black, Mushtaq, Baddeley, \& Kapur, 2020). Of course, this will be very helpful for students in dealing with the strict educational curriculum in universities which are so many and varied. Technological advances that grow rapidly also develop into application development, one of which is the presence of the Digital Al-Quran Application. This, of course, can make it easier for everyone to be more intense and frequent in interacting with the book of Allah.

The teachings contained in the Al-Quran are actualized into a routine of worship that aims to lead to ma'rifatullah. Sufism and Sufi are areas that are in direct contact with the study of ma'rifatullah. Research studies related to Sufism and Sufism have been carried out by many Muslim and non-Muslim intellectuals. Within the scope of modernity, the study of the Sufistic area seems to have encouraged western scholars to study and develop the Sufistic tradition, which tends to play an essential role in the religious values of modern society. Joseph E.B Lumbard, a Western researcher, tried to analyze the Sufistic teachings developed by Hujjatul Islam Abu Hamid Al-Ghazali (Lumbard, 2016).

Furthermore, Robert Landau Ames, a researcher from Harvard University, explored the theory of public intellectual and the concept of Mīzān al-Ma'rifah, a modern Sufi and social-minded Șafì 'Alī Shāh', an Iranian national, one of the influential Sufi figures there (Ames, 2018). In Australia, a study was conducted by Milani to examine the Sufi and spiritual concepts of Tariqah Naqshbandiya (Milani \& Possamai, 2015). Changes in the dimensions of human civilization towards modernity slightly reduce spiritual values and theology of belief in God, so, naturally, the significance of Sufism is so urgent and essential to regenerate the religiosity of modern society in Western and European countries (Alıcl, 2019; Auer, 2019; Held, 2017; Kars, 2018; Montgomery, 2012; Palmer, 2018; Saramifar, 2018).

Sufism in Islamic teachings has a significant role in the search for human identity to know God. Morality and Divine Theology will be perfect when wrapped in the principle of al-ihsan as indicated in Jibril's hadith (Al-Haramain, 2011). The importance of the Sufi ritual has undoubtedly attracted the attention of many classical and contemporary scholars to design the formulation of the Sufi tradition and its stages that are dynamic, systematic, and flexible based on the book of Allah and the Sunnah of the Prophet. Classical Muslim scholars such as Al-Ghazali, Al-Qushairi, and At-Tusi view that the highest peak of 
a Sufi's journey of maqām to reach his God is maqām ridhā (stage of satisfaction). Unlike them, Rabiah Al-Adawiyah believes that the rise of the maqam level is mahabbah Allah (Love of Allah). Jalaluddin Ar-Rumi argues that the peak of a Sufi's station is fanā (death) and baqā (union with divine life) (Ni'am, 2020). According to tasawwuf scholars, doing dhikr and always asking for repentance to cleanse heart disease will open the gate to ma'rifatullah.

The era of modernity encourages tasawwuf scholars to develop tasawwuf methods that are in line with the culture development of modern society. One of the well-known scholars who pay serious attention to this aspect is Ali Jum'ah, a charismatic cleric from Egypt. In terms of experience, he has served as a former Mufti of Egypt who played a role in the authority to take fatwas related to Islamic jurisprudence discourse. In addition, he is a senior scholar at Al-Azhar University, Cairo, Egypt, so that many scholars throughout foreign countries make the opinion of Sheikh Alī Jum'ah as a scientific reference. The author, on this occasion, tries to explore deeper related to the conceptual and application of the methods and patterns contained in the construction of his thoughts in his work AtThariq Ila Allah. The significance of this research is expected to make a significant contribution in realizing individual piety for the young generation, especially students, and strengthening the Islamic Religious Education curriculum in universities. The author sees that the concept he offers is a Sufistic concept suitable for contemporary society in the 4.0 era; besides being practical and efficient, his ideas are thick with the wasathiyyah direction, namely trying to provide balance in all aspects of human life. The research problems that are formulated in this research study are how the Sufistic concept of Sheikh Ali Jum'ah is in the era of modernity, and what the implications of applying the Sufistic concept of $\mathrm{Al} \mathrm{Jum}$ 'ah are in the learning strategy of Islamic Religious Education (PAI) in Higher Education.

\section{RESEARCH METHOD}

This research study in its implementation as well as the application of its methodology was carried out in two stages: 1) Library Research, namely examining and exploring the Sufistic works of Prof. Dr Ali Jum'ah. The main source is studied from his work entitled "At-Thariq Ilallah" (The Way to Allah SWT), while other secondary works are Al-Bayān Limā Yasyghulu Al-Adzhān, As-Silsilatu An-Nūrāniyyatu fĩ At-Tarbiyyah ArRabbāniyyah, Sabīlu Al-Mubtadi'īn fī Sharh Al-Bidāyāt Min Manāzili As-Sāirīn, Khuthuwātu Al-Khurūj Min Al-Ma'āsī, and several others, and 2) the second stage is to formulate the relevance of modern Sufistic studies and theoretical studies of Islamic Religious Education in Higher Education. 


\section{RESULTS AND DISCUSSION}

\section{The Problematic Dynamics of Tasawwuf Discourse Among Ulama}

\section{Definition of Tasawwuf Terminology and Argumentative Theorems of Al-Quran and Hadith}

Tasawwuf is etymologically derived from the Arabic word, namely tashawwafayatashawwafu where the primary meaning is taken from the phrase shuf, which means fleece, where this intention is interpreted that with tasawwuf a person navigates his life, but upholds noble character with the purity of heart. In the Arab tradition in the past, local people saw that wearing clothes made of coarse wool was a symbol of simplicity. This is the forerunner of how the Sufis have a paradigm that when they stand before Allah, they are like a feather that means nothing, does not mean anything. Most scholars such as Imam Al-Junaidi, Shaykh Abdul Qadīr Al-Jaelānī, Imam Ibn Ajibah, and other Sufi scholars associate tasawwuf activities with the process of cleansing and purifying the soul. In harmony with most scholars, Sheikh Ali Jum'ah emphasized that the bond between a servant and Allah SWT can only be built by cleansing the heart from submission to creatures to submit only to Khaliq (Jum'ah, 2007). Although there are different narrations in defining the meaning of Sufism or Sufism, they generally agree that a servant who enters the door of ma'rifatullah must be fully oriented to improve the soul from deviant behaviors and sins by purifying the heart (Jum'ah, 2008a).

Furthermore, Sheikh Ali Jum'ah saw that tasawwuf is an integral part of the principles of the Islamic religion. In the Qur'an many verses allude to the process of cleansing the soul in the context of taqarrub to Allah SWT. Among the poems related to this is QS. Al-Ala' verses 14-15, QS. Ar-Rad verse 28, QS. Al-Maidah verse 54, QS. At-Tahrim verse $8, \mathrm{QS}$. At-Thalaq verse 3, and so forth. Sheikh Alī Jum'ah viewed at least three principal aspects of religion that most scholars agree on, namely the aspect of faith, the aspect of sharia, and the aspect of morality. In formulating the those three aspects, Sheikh Ali Jum'ah, in addition to taking references to the Qur'an, also tried to refer to the hadith of Jibril (as) who was in contact with the Prophet Muhammad as the argumentative basis for this discourse, where the Prophet Muhammad said:

Umar bin Khattab said: Once, we (the companions) sat near the Prophet sallallaahu 'alaihi wa Sallam. Suddenly a man appeared to us wearing white clothes and black hair. There was no visible sign of the journey, and neither of us recognized him. He immediately sat in front of the Prophet, then his knees leaned against the Prophet's knees and put his hands on the Prophet's thighs, then he said: "O Muhammad! Tell me about Islam." The Prophet sallallaahu 'alaihi wa sallam replied, "Islam is, you testify that no one has the right to be worshiped except Allah and that Muhammad is Allah's Apostle; establish prayer; pay zakat; fasting in the month of Ramadan, and you make the pilgrimage to the Baitullah, if you have been able to do it," the man said, "You are right," so we were surprised, he who asked he also confirmed it. Then he asked again: "Tell me about Faith." The Prophet replied, "Faith is, you believe in Allah; His angels; His books; His Apostles; the Last Day, and believe in Allah's good and bad destiny," he said, "You are right." He asked again: "Tell me about Ihsan." The Prophet sallallaahu 'alaihi 
wa sallam replied, "You should worship Allah as if you see Him. Even if you don't see Him, He sees you..." [Muslim]

From the hadith history above, conceptual faith, Islam, and Ihsan are described in the framework of belief represented in monotheism, or the science of kalam which discusses faith in Allah SWT and others. Furthermore, Islam is described in the science of fiqh, and ihsan is represented in the science of tasawwuf. Sheikh Alī Jum'ah's views regarding these three aspects have at least been legalized by most scholars; although there will still be those who disagree with his opinion, this is only a tiny part. According to the contemporary scholar, Mahmūd Yūsuf in his book mafhūm at-tashawwuf wa anwā'uhu fì al-mīzān as-syar'ī explains at least there is some urgency in the study of tasawwuf in the thought map of Muslim scholars, including 1) Tasawwuf is a bridge to build the spiritual aspect of humans towards humans. Kamil, 2) studies related to tasawwuf are the literary treasures of Muslim intellectual heritage recorded in history books, so of course, this is a positive part in building intelligent Islamic civilization, 3) tasawwuf can be a solution to all human problems in the dimension of modernity, 4) tasawwuf can be a way to correct erroneous understandings, 5) Strengthen the functions of the limbs to be in line with Islamic sharia, and 6) Realizing happiness both in this world and in the hereafter (Yusuf, 2002).

\section{Steps of the Salih Salafist Scholars in Formulating the Concept of Sufism}

Sheikh Alī Jum'ah argued that in the Sufistic tradition that is developed among Sufi experts, which was transformed into a manhaj which his followers followed through tariqah, at least he formulated two methods that were built in preparing practical practices in a tariqah either in the form of aurad and charity worship, namely firstly actualizing the content contained in the Al-Quran and Sunnah and secondly, through the process of tadrīb and mujāhadah that they do in embodying one amaliyah in the form of aurad and certain amaliyah (Jum'ah, 2008a). According to Alī Jum'ah, these two steps must be contained in one formulation of tasawwuf, namely in harmony with the principles contained in the Qur'an and Sunnah, then through the process of consistency of a murshid with the efforts of tadrīb and mujāhadah in practicing a particular practice that can bridge the ma'rifatullah. The experience of a murshid in Ali Jum'ah's view is the core composition to open a manhaj in the context of tasawwuf. At least, the above has been done by mu'tabarah tasawwuf experts in the process of twists and turns in their journey to reach ma'rifatullah as experienced by sulthan auliya Sheikh Abdul Qadir Jaelanī, Sheikh At-Tijānī, Sheikh AsSyādzilī, and others.

The phrase that is often heard among Sufi experts related to the dynamics above is "Man Dzāqa Arafa, Wa Man Arafa Igtarafa" which means whoever tries to feel something trying to feel the pleasure of worshiping Allah, then he will come to the door of ma'rifah, and who has been wise, then he will continue to dive into its depths. Imam Al-Ghazālī ra, in his book Ihyā Ulūmuddīn (Al-Ghazali, 2008), photographing the statement of Abu Bakr Ash-Siddiq where he said, which means: "Whoever feels the pleasure of sincere love for Allah, then he will be busy with it instead of begging for the world". 
This expression portrays that the more Sufism scholars feel the pleasure of faith and the process of worshiping Allah, the more they will not be surprised if they continue to dive into it, asking for ziyādah (additional) no one will be able to break it. This is even indicated by Imam Ibn Qayyim ra in his book Al-Zuhud wa Al-Wara' wa Al-Ibādah that a person can feel the pleasures of worship accompanied by a sense of sincerity Allah SWT then he will get everything that Allah SWT gives that is not given to others. It means that a person's success may be directly proportional to how much commitment he has in the context of taqarrub to Allah SWT with a pure heart and sincerely expecting for His pleasure.

In line with the above description, Sheikh Ali Jum'ah noted that in the history of Islam, historical portraits prove it where King Najasi at that time was curious about the da'wah of Islam so that when Abu Sufyan came to face him, he asked him, "are they increasing or are they decreasing?". Then Abu Sufyan replied: "they increase." Then the king replied: "as well as with faith it is difficult to escape if it has entered the depths of one's heart." The dialogue that was photographed between King Najasi and Abu Sufyan illustrates that the faith that has entered the recesses of a person's heart will be complicated to bring out again. The scholars constructed the science of Tasawwuf with the main aim of bridging humans in climbing the stairs to the God. However, Sheikh Al Jum'ah applied strict rules where the practice of tasawwuf will always be in the corridor of religion when it is in harmony with the values of the teachings contained in the Qur'an and Hadith.

At this time, there are many actions carried out by the enemies of Islam who seek to propagate attacks against the legality of Sufism teachings. They allege that many Sufi experts are currently carrying out practices that deviate from religious teachings. They allege that the events of khāriqul ā'dah or karāmah showed by the waliyullah are the actions that are contrary to the Qur'an and As-Sunnah, and were not taught by the Prophet Muhammad and his companions. According to Sheikh Alī Jum'ah, the views of this extreme group are not following the majority of the opinions of the scholars. He even reminded the powerful groups to be careful in accusing the saints of Allah with unkind accusations because this could be a danger to the person who could have his blessings revoked by Allah SWT for slandering Allah's lovers with wrong charges. Even a high Islamic scholar named Muhyiddin ibn Al-Arabi said, "At-Tashdiq bina Territories" which means believing and confirming we may be entering the territory. The saints of Allah in general they keep their hearts busy with Allah; they keep the worldly busyness away.

The group claiming they are special people but never establish prayer is the zindīq group. The group that develops prayers but never pay attention to the impact of their prayers, immoral acts are constantly being carried out, then they may be considered as fasiq people. The Sufi scholars in harmony with the creed of the Ahlu Sunnah wal Jama'ah perform prayers and combine them with the effects on the tazkiyatun nafs (selfcompassionate), abstaining from immorality, then they are the group that is truly in harmony with the uswah (the model) of the Prophet Muhammad. The above rules are set in order as a means of control in the process of a salik's journey to his Lord. The journey is so long and tiring, some many obstacles and challenges come from both internal and 
external, requiring a comprehensive and correct understanding to minimize things that are contrary to the religious teachings.

\section{Ali Jum'ah Sufistic Rules in the Process of Spiritual Traveling to the Door of Ma'rifah}

The door of ma'rifatullah in $\mathrm{Al}$ Jum'ah's view must be passed by a servant gradually by referring to the traditions of the Sufism scholars. Following them, at least minimizing the challenges and obstacles that will be faced in their journey. According to Ali Jum'ah in his book At-Thariq Ila Allah, six main rules must be followed, including:

\section{Allāh Maqshūd al-Kulli}

The fundamental principle in the process of a sālik's journey to his Lord is that when he determines "Allah Means Kulluhu" Allah is the primary goal. This expression is an expression that is so firm, becomes the central pillar of the human journey towards the God. In the Sufistic tradition that the Murshids have cultivated, when accepting a student to later becomes his disciple, surely a murshid will ask, "what is your goal in studying this science?", then he answered: "Allah." The Aulia set the only target in the process of wandering in this world only for worshiping Allah SWT. This has been exemplified by the Prophets and Apostles, who all agreed that Allah alone has the right to be worshiped (AlQardhawi, 1990, 2007).

\section{Anna Multafitan fì Tharīq ilā Allāh Lā Yashilu}

The majority of the Sufis believe that the above rules will significantly determine the goal of a servant, whether he will reach his Lord or not? This can be analogized in a simple example when someone plans to travel to a place, then surely that person must try and make every effort to remain istiqamah (firm) and strict in every step until he reaches his final destination. He will encounter many obstacles in his journey. Therefore, it takes a solid and determined determination so that the journey's goal is only to reach the endpoint. This process in the Sufistic world can be said that anyone who is careless and turns away will never come to his Lord. Imam Shafi'i ra once said: "I have interacted with Sufi experts, so I conclude from this study that time is like a sword; if you cannot cut it, it will cut you". The sincerity of intention is the primary concern of Islamic scholars in recent studies (Al-Arefe, 2011; Rawwas, 1988). They try to preach the sentence of monotheism as the aim of life (Jum'ah, 2008c, 2014).

The firmness of the above rules implies that there is an urge in a servant to do any worship only to get the pleasure of Allah SWT, not to turn to the lights that he will find during his journey, nor to look to the secrets that maybe Allah SWT will open the ta'bir, not to the malakut, or others, the sole purpose of this tasawwuf process is only to get Allah's pleasure. Focusing on the goal of achieving the pleasure of Allah is a part of etiquette and ethics to Allah SWT. When a servant makes dhikr, then the paradigm he builds is that his dhikr that will cleanse his heart of meaningful impurities so that clarity will become a way to the God like a mirror; when on the surface is clean, there is no dust at all, then he will be able to see himself very clearly. When a person's heart is clear as a mirror, he will receive the divine light that is very special in him (Jum'ah, 2008c). 


\section{Wujūdu asy-Syaikh al-Murabbī Dharūratun fĩ as-Sayr ilā Allāh}

The existence of a sheikh or murshid is essential and should not be neglected in the sufistic journey of a servant because he is the one who will guide and direct which paths to follow and which ways to avoid, which practices must be suppressed, and which techniques should be better prioritized. Then, where does a murshid get his method and manhaj? The answer is from the experience and practice that he did which did not conflict with the Qur'an and Hadith; it could even be that his method was the result of what he had done to the two primary sources above as exemplified by the Prophet Muhammad with his companions, as well as with the Prophet Muhammad SAW's tabi'in. Sufi experts classify murshid into several categorizations: first, Sheikh Murshid is someone who has known and understood the journey to his Lord and knows the challenges in the process, and he knows how to avoid it, as well as he teaches etic to his God. A murshid conducts the initial approach from the ethics to Allah; firstly is Dhikr, then secondly, do not turn away from Allah's only goal. Second, Mursyid Tam (Perfect Murshid) can be called the heir of the Prophet Muhammad. Sometimes, a Murshid Tam will be opened by Allah, even from his students; why is that? Because of the clarity of his heart and his perfect sincerity to his Lord. Finding a Murshid Tam is more important than just a Murshid. However, finding such a person can only be met by people. Allah has given him rizki to meet with mursyid tam.

\section{Anna Al-Ibrah Biman Shadaqa wa Laisat Biman Sabaqa.}

The word shadaqa in Arabic terminology means sure. In the world of Sufism, there is one famous formula by which faith can speed up the process. This means that people who genuinely believe and want to apply what is taught by their Murshid (teacher) may arrive earlier than other people who have been at the beginning but do not have the quality of strong belief in Allah. This rule captures that sometimes certain people enter the journey, but it seems that they have arrived at their destination without taking long. An example is our Prophet Muhammad SAW, where he was the seal of the Prophets, but he eventually became their Imam. His life can be used as a role model to strengthen belief in Allah SWT and implicate his commands in social interactions in his day (Jum'ah, 2012). This lesson is fundamental, especially concerning renewing intention and motivation. Faith can shorten such a great distance. From here, everyone who tries and wants to go through the process of his path, then the key is the purity of the goal only to Allah, Allah is the only goal. In educating his students, a sheikh/ murshid teacher must have unique characteristics and competencies and have good moral ethics. These qualities must be in harmony with the elements exemplified by the Prophet Muhammad SAW (Rawwas, 1988).

\section{Anna Khalwatana fi Jalwatinā.}

The meaning of the above expression is to glorify God in a state of khalwah (alone) without appearing to anyone, primarily if it is carried out at night in a state of ablution and wearing white clothes, it should help the process to the God even though it is not a principle. The primary key is that good student are encouraged to pray for dhikr to Allah according to their abilities and conditions. This is in line with Nubuwwah's cue where Rasulullah SAW said, "a person came to the Prophet and said: "O Messenger of Allah there 
are so many Islamic Sharia, can you show me one practice which I stick to that practice?" Then the king replied: "Your tongue is always wet with the remembrance of Allah." A tongue that often remembers Allah will cause a dry condition, but this dryness is a good thing, and in the perspective of Islam, it is a unique practice. Like a person who is fasting, although his mouth may have a scent that is less than moderate in the eyes of humans, from a religious perspective, his mouth smells better than musk oil. What are the factors? Because he did it to get closer to Allah SWT.

\section{Ad-Daymumah lā Al-Amali.}

Another important rule is consistency in amaliyah. Rasulullah SAW is a Prophet, and the Apostle has a very high level of consistency. He invites his friends to always do one practice by applying a solid standard of character. In a Hadith narration, the Prophet SAW said: "The practice that Allah most loves is the most consistent even if it is a little." Another narration narrated by Sayyidah Aisyah ra describes the characteristics of the Prophet Muhammad, where she said: "The practice of the Prophet SAW is carried out consistently" the meaning is continuous continuity.

The Sufi experts are vital in maintaining this consistency; that's why there is a famous phrase in their world, "Idza Inqatha'a Al-Wird, Inqatha'a Al-Waarid" if dhikr is interrupted, then the person who proceeds is cut off. Whoever the student who does not desire one practice and does not strive for it, for example carrying out one day but doing it the next day, then his efforts in the process towards Allah will be cut off. Sufi experts describe that amaliyah wirid is symbolized as a development process as if the student is designed to establish a building, so he must strive for the building every day to be consistent in the building. To not get cut off, it is recommended starting with the remembrance of Laa Ilaaha Illallah, reading 100 times a day. According to the student's ability, the principle is that you should not force it if you are not ready. According to his ability, he can start from 100 times per day, can be 200 times, can be 500 days. Do not be in a hurry in reciting dhikr; enjoy every dhikr that we read.

\section{The Concept of At-Taubah, Al-Fikru, Al-Dzikru, the Main Gate of Ma'rifatullah}

In the view of Sheikh $\mathrm{Al}$ Jum'ah, a salik who wants to take the stairs to ma'rifatullah, three activities must be carried out consistently in his life, namely repentance from immoral acts thinking phenomena natural and personal, and always consistent in dhikr (remembrance) to Allah SWT (Jum'ah, 2008a) and (Jum'ah, 2008b). To enter the world of Sufism, clarity of heart and submission to Allah SWT is the only door that a student must pass. Abandoning immorality in all its forms is the first step that must be taken to increase religiosity and spirituality to the God. Repentance from degeneration is an obligation that has been determined by religion to be immediately carried out by humans. This has become ijma' among the fuqaha since the development of fiqh after the Prophet's death until now. Repentance is one of the essential principles of Islam and part of the pillars of religion; repentance is the first door of the students to their Lord. Allah SWT says in the Qur'an, which means: "and say to the believing women, that they should guard their eyes, and guard their private parts, and do not reveal their adornments (aurat), except what is (usually) visible." 
According to Sheikh Wahbah Al-Zuhaili, the condition for repentance of naasuha must at least consist of four main requirements: 1) Removing the sin from him, 2) Regretting what has been done in the past, 3) Having strong determination not to repeat the mistake, and 4) Returning the rights that do not belong to him (Az-Zuhailī, 1997). In line with Al-Zuhaili, Abu Bakr Al-Jazairi in his commentary, recommended for someone to immediately repent because this action can open the way to the door of blessing and success both in this world and in the hereafter. (Al-Jazāirī, 1990). Imam Ibn Kathir also emphasized that the absolute requirement for success in interpreting the above verse is concluded in two things: carrying out all the commands of Allah and staying away from all His prohibitions (Katsīr, 1999). Humans need repentance at all times because this is a part of Allah's commandment, especially Nasuha's (serious) repentance from all forms of immorality, and orders the humans to not repeat the mistakes forever.

If we pay attention to the narration of the Nabawi text when talking about the discourse of Repentance Nasuha, it will be very diverse. One of them is a hadith narrated by Muadz bin Jabal:

Rasulullah SAW said: "Repentance Nasuha is someone who regrets the sin that he has done, then asks forgiveness from Allah SWT accompanied by the intention not to do it as milk does not return to its place."

From the narration of the hadith above, the scholars see that Nasuha's repentance is essentially intending not to do it again after being guilty. There are also among the scholars who argue that repentance of Nasuha must include four components: 1) deep regret by the heart, 2) saying istighfar sentences by mouth, 3) removing the sin, and 4) tumha'ninah as an effort not to do it again. A servant must always seek repentance; repentance has enormous benefits in the human journey towards his Lord. Rasulullah SAW has carried out the activity of repentance in his life. In a narration, he said which means: "O people, repent to Allah; indeed I repent to Him 100 times a day."

Repenting, dhikr, and meditating in the Sufistic area play a huge role towards the door of ma'rifatullah. Therefore, according to Sheikh Ali Jum'ah, it is recommended for a Muslim to always not leave the practice every day. Because according to him, the door of success and blessing both in the world and in the hereafter will always have a connection with the amaliyah (deeds) as a bridge to have a relationship with Allah SWT.

\section{Implications of Alī Jum'ah's Sufistic Thought on Islamic Studies (PAI) in Higher Education}

What is meant by implication in this study is a concept implied by Ali Jum'ah's Sufistic thought that can be applied to the idea of PAI learning in universities is presented in the following discussion.

From the results of the study of Ali Jum'ah's Sufistic thought, it can be concluded that Al Jum'ah emphasizes the existence of a fundamental principle in the journey of a salik (an obedient servant) to his Lord, namely six principles must be followed, namely: (1) only Allah is the goal; the only one in life, (2) a salik in carrying out the world of Sufism must be straight in his intentions only for Allah because if he turns a direction, it will not arrive to the destination, (3) the existence of a murshid is essential and should not be ignored in a 
person's Sufistic journey, (4) in the world of Sufism, there is a famous formula where belief in Allah can speed up the process to achieve ma'rifah (enlightenment), (5) glorify the God in a state of kholwah (alone) at night in a state of ablution and wearing white clothes is better, and (6) consistency in amaliyah (deeds).

In Ali Jumu'ah's Sufism thought, the process of spiritual traveling to the God must combine knowledge, ma'rifah, and acts of worship. The formulation is that expertise, ma'rifah, and amaliyah (deeds) are carried out simultaneously so that it has an impact on the process of feeling and enjoying the journey so that entering this area means that a person will arrive at ma'rifah, then a person who has achieved ma'rifah will undoubtedly continue to explore its depths so that the veil between himself and his Lord is opened. In addition, in the thought of Sufism Ali Jumu'ah, a student must perform tazkiyatun nafs, abstain from sinful acts, and multiply repentance to Allah. By referring to Ali jum'ah's Sufistic thinking, the implications for PAI learning in higher education, especially the implications for PAI learning objectives, PAI learning materials, PAI learning approaches, PAI lecturers, and PAI students, are as follows:

\section{Implications for PAI Learning Objectives in Higher Education}

The implications of Ali Jum'ah's Sufistic thinking above on the objectives of PAI learning in Higher Education are: (1) PAI learning objectives must be directed following the purpose of human life itself, namely the students direct their life goals only to the God; (2) PAI learning objectives must really be able to lead students to become human beings who are ma'rifah to the God, and (3) PAI learning objectives must be oriented not only to the interests in the world for a moment, but must be oriented far ahead in the form of spiritual goals following the ultimate goal of human life itself that is to meet the God and find happiness by His side.

\section{Implications for PAI Learning Materials in Higher Education}

The implications of Ali Jum'ah's Sufistic thinking above on PAI learning materials in universities are (a) PAI material, in addition to covering studies on aqidah, worship, and morals as in general, there must also be a study of Sufism that leads students to be able to achieve ma'rifah to Allah, (2) PAI learning materials are not given only in the cognitive area in the form of understanding or intellectual intelligence, but there must be studies that touch the heart (affective) and psychomotor areas, and (3) In PAI learning there must be practical practices that can encourage students to be able to practice what is received in the learning process in class.

\section{Implications for PAI Learning Approaches in Higher Education}

The implications of Ali Jum'ah's Sufistic thinking above on the PAI learning approaches in Higher Education can be done through: (1) an experiential approach, namely providing religious experiences to students to instill Sufism values by entering into the world of Sufism, so that can achieve ma'rifah and feel closeness to the God, (2) habituation approach, namely students get used to practice what is taught in Sufism, such as increasing sunnah prayers, increasing dhikr, controlling lust, and increasing repentance 
to Allah, and (3) exemplary approach, namely how students appear as role models in everyday life for other students.

\section{Implications for PAI Lecturers in Higher Education}

The implications of Ali Jum'ah's Sufistic thinking above for PAI lecturers in universities are: (1) PAI lecturers in universities need a pious lecturer, a personal figure of a lecturer who appears as an educator who can provide an example to his students, a personal figure of a lecturer who appears as an uswatun hasanah (good model) figure in all aspects of his life, and this is the key to the success of PAI in Higher Education; (2) PAI lecturers in universities must perform prophetic roles, and that view is not excessive. In a sense, a PAI lecturer at a university must be able to take lessons about how the Prophets taught Islamic teachings to their people; and (3) PAI lecturers in universities are not just masters of knowledge about Islamic education, but must be people who can practice the theory of faith. In everyday life, they become role models for their students.

\section{Implications for PAI Students in Higher Education}

The implications of Alī Jum'ah's thinking above for students in PAI learning in Higher Education, namely: (a) the students must obey the lecturer, carry out what is conveyed by the lecturer in learning, including doing the tasks given by the lecturer; (b) to be able to understand what the lecturer conveys in the learning process, the students must focus on learning and be accompanied by a sense of sincerity in attending lectures, so that the knowledge they receive can be helpful, leading to happiness in the world and the hereafter; and (c) the students have to know the ethics of dealing with lecturers, both in speaking and in attitude and behavior.

\section{CONCLUSION}

From the description of Ali Jum'ah's Sufistic thinking and its implications for PAI learning in Higher Education, it can be concluded that Ali Jum'ah is one of the charismatic contemporary scholars who try to initiate and develop a Sufistic conceptual that is in line with the changing times at this time. Sufism is an integral part that cannot be separated from Islam whose content is sourced from the Al-Quran and As-Sunnah and experiments carried out by pious people within the framework of the Al-Quran and As-Sunnah. Furthermore, according to Ali Jum'ah, six principles are principled in Sufism, namely: (1) only Allah is the human's only purpose in life, (2) a seeker must be straight with his intentions only for Allah, if he turns a direction, then he does not will arrive to his destination, (3) the existence of a murshid (spiritual teacher) is essential and should not be neglected in the sufistic journey of a servant, (4) in the world of Sufism there is a famous formula where belief can speed up the process to achieve ma'rifah, (5) glorify the God in a state of khalwah (alone) at night in a state of ablution and wearing white clothes is better, and (6) consistency in practice. In addition, in the view of Sheikh Alī Jum'ah, a salik who wants to take the stairs to ma'rifatullah, then three activities must be carried out consistently in his life, namely repentance from immoral acts, thinking phenomena both natural and personal, and always be consistent in dhikr (remembrance) to Allah SWT. 
Then, the implications of Ali Jum'ah's Sufistic thinking on PAI learning in universities are: First, the objectives of PAI learning must be directed following the purpose of human life itself; it must be able to lead students to become human beings who believe in Allah with confidence. He believes, must be more oriented towards spiritual goals to obtain happiness in the hereafter. Second, PAI learning materials must have a study of Sufism and ma'rifatullah, emphasize the affective and psychomotor aspects, and worship practices that can encourage students to practice what is received in the learning process in class. Third, the PAI learning approach in universities must use a religious experience approach by entering the world of Sufism, a habituation approach, such as increasing sunnah prayers, increasing dhikr, controlling lust, and increasing repentance to Allah, and an exemplary method, namely how lecturers are role models for their students. Fourth, PAI lecturers at universities must have pious personalities, appear as educators who can provide examples to their students, must carry out prophetic roles in the sense that a PAI lecturer must be able to take lessons about how the Prophets taught Islamic teachings to their followers, and not only master the science of Islamic education but must be people who have been able to practice the theory of Sufism. Fifth, the students in PAI learning at universities must obey the lecturers, focus on learning, be accompanied by a sense of sincerity in attending lectures, and know the ethics of dealing with lecturers, both in speaking and in attitude and behavior.

\section{REFERENCES}

Al-Arefe, M. bin A. (2011). Istamti' Bi Hayātika Funūn At-Ta'āmul Ma'a An-Nās fì Dzilli AsSïrah An-Nabawiyyah. Saudi Arabia: Sarikah Muslim.

Al-Ghazali, A. H. (2008). Ihya Ulumuddin. Beirut: Dar Ibnu Hazm.

Al-Haramain, E. (2011). Shifting Orientation in Sufism : its Development and Doctrine Adjustment in History. Indonesian Journal of Islam and Muslim Societies, 1(2), 273296. https://doi.org/10.18326/ijims.v1i2.273-296.

Al-Jazāirīi, A. B. J. (1990). Aysaru At-Tafāsīr Li Kalām Al-Alī Al-Kabīr. Jeddah: Racem.

Al-Qardhawi, Y. (1990). Awlawiyyat Al-Harakah Al-Islamiyyah. Cairo: Dar An-Nasyr wa AtTauji'.

Al-Qardhawi, Y. (1996). Al-Ijtihād Fī As-Syarī’ah Al-Islāmiyyah. Cairo: Dar Al-Qalam.

Al-Qardhawi, Y. (2007). Ushūl Al-'Amal Al-Khairī Fī Al-Islām Fī Dhaui An-Nushūsh Wa AlMaqāsid As-Syarī'ah. Cairo: Dar As-Syuruq.

Al-Rawashdeh, M. S. (2014). The Impact of Globalization on the Political Culture of the Arab Youths. Journal of Middle Eastern and Islamic Studies (in Asia), 8(4), 81-120. https://doi.org/10.1080/19370679.2014.12023250.

Alıcl, G. (2019). Arabic Literature of the North Caucasian Naqshbandiyya in the 19th Century Shaykh Jamāl al-Dīn al-Ghāzīghumūqī's Treatise al-Ādāb al-Marḍiyya fī lȚarīqa al-Naqshbandiyya and Its Khālidiyya Tendencies. Die Welt Des Islams, 8, 5076. https://doi.org/10.1163/22105956-12341315. 
Ames, R. L. (2018). Weighing Knowledge Humanity, Modernity, and Șafī ‘Alī Shāh's Mīzān al-ma'rifah. Die Welt Des Islams, 7, 165-194. https://doi.org/10.1163/2210595612341312.

As-Shalabi, A. M. (2008). As-Sirah An-Nabiwiyyah Ard Waqa'i Wa Tahlil Ahdats (p. 934). Dar Al-Ma'rifah.

Auer, B. (2019). The Origins and Evolution of Sufi Communities in South Asia Revisited. Die Welt Des Islams, 8, 30-49. https://doi.org/10.1163/22105956-12341314.

Az-Zuhailī, W. bin M. (1997). At-Tafsìr Al-Munīr fì Al-Aqïdah wa As-Syarīah wa Al-Manhaj. Beirut: Dar Al-Fikr Al-Mu'ashir.

Black, R., Mushtaq, F., Baddeley, A., \& Kapur, N. (2020). Does Learning the Qur'an Improve Memory Capacity? Practical and Theoretical Implications. Memory, 28(8), 10141023. https://doi.org/10.1080/09658211.2020.1811347.

Bruner, R. F., \& Iannarelli, J. (2011). Globalization of Management Education. Journal of Teaching in International Business, 22(4), 232-242. https://doi.org/10.1080/08975930.2011.653908.

Ghadhban, M. M. (1992). Fiqh As-Sirah An-Nabawiyyah (p. 752). Jami'ah Ummur Qura.

Goodwin, A. L. (2020). Globalization, Global Mindsets and Teacher Education. Action in Teacher Education, 42(1), 6-18. https://doi.org/10.1080/01626620.2019.17008 48.

Held, P. (2017). Comparing the Teachings of 'Abd al-Qādir al-Jīlānī and Abū Madyan. Die Welt Des Islams, 6, 165-189. https://doi.org/10.1163/22105956-12341301.

Islamy, M. R. F., Supriadi, U., Rojak, R. W. A., Romli, U., Anwar, S., \& Parhan, M. (2020). Tanfidz Ta'lim As-Syahsyiyyah Dirasah Tahliliyyah Fi Ma'had Al-Inayah Bandung. Lentera Pendidikan, 23(2), 343-356. https://doi.org/10.24252/lp.2020v23n2i61 3.

Jum'ah, A. (2007). As-Silsilatu An-Nūrāniyyatu fĩ At-Tarbiyyah Ar-Rabbāniyyah. Kairo: Syirkah Al-Wabil Ash-Shayyib.

Jum'ah, A. (2008a). At-Tharīq Ilallah. Kairo: Al-Wabil Ash-Shayyib.

Jum'ah, A. (2008b). Khuthuwātu Al-Khurūj Min Al-Ma'āsī. Kairo: Markaz Ad-Dirāsāt AlManhajiyyah wa Al-Ma'rifiyyah.

Jum'ah, A. (2008c). Sabīlu Al-Mubtadi'în fi Syarh Al-Bidāyāt Min Manāzili As-Sāirīn. Kairo: Syirkah Al-Wabil Ash-Shayyib.

Jum'ah, A. (2012). An-Namādjiji Al-Arba'ah Min Hadyi An-Nabī fi At-Ta'āyusy Ma'a Al-Ākhar Al-Asas wa Al-Maqāshid. Mesir: Dār Al-Fārūq Lil Istitsmārāt At-Tsaqāfiyyah.

Jum'ah, A. (2014). Al-Kutub Al-Mukawwanatu Lil Fikri Al-Islāmī As-Sunnī. Jordania: AlMamlakah Al-Urdūniyyah Al-Hāsyimiyyah.

Kars, A. (2018). Companionship, Human Perfection, and Divine Union in ThirteenthCentury Persian Sufism. Die Welt Des Islams, 7, 74-101. https://doi.org/10.1163/22105956-12341308.

Katsīr, A. A.-F. I. bin U. bin. (1999). Tafsīr Al-Qurān Al-Adzīm. Riyadh: Dar Thayyibah.

Kinkead-Clark, Z. (2017). Early childhood care and education in Jamaica. Stakeholders' Perceptions of Global Influences on A Local Space. Early Child Development and Care, 187(10), 1484-1495. https://doi.org/10.1080/03004430.2017.1319825. 
Law, W. W., \& Ho, W. C. (2009). Globalization, Values Education, and School Music Education in China. Journal of Curriculum Studies, 41(4), 501-520. https://doi.org/10.1080/00220270802372329.

London, J. D. (2010). Globalization and the Governance of Education in Viet Nam. Asia Pacific Journal of Education, 30(4), 361-379. https://doi.org/10.1080/02188791.2010.520202.

Lumbard, J. E. B. (2016). Ahmad al-Ghazālī, Remembrance, and the Metaphysics of Love. In New York Press. https://doi.org/10.1163/22105956-12341303.

Machingambi, S. (2014). The Impact of Globalisation on Higher Education: A Marxist Critique. Journal of Sociology and Social Anthropology, 5(2), 207-215. https://doi.org/10.1080/09766634.2014.11885625.

Mah, J. S. (2002). The Impact of Globalization on Income Distribution: The Korean Experience. Applied Economics Letters, 9(15), 1007-1009. https://doi.org/10.1080/13504850210149124.

Milani, M., \& Possamai, A. (2015). Sufism, Spirituality, and Consumerism : The Case Study of the Nimatullahiya and Naqshbandiya Sufi Orders in Australia. Contemporary Islam, 1-19. https://doi.org/10.1007/s11562-015-0335-1.

Montgomery, D. W. (2012). Nicolaas Biegman, Living Sufism : Sufi Rituals in the Middle East and the Balkans. Contemporary Islam, 6, 199-200. https://doi.org/10.1007/s11562-010-0142-7.

Mucharomah, M. (2017). Pendidikan Karakter: Sebuah Visi Islam Rahmatan Lil Alamin. Edukasia Islamika, 2(2), 191-207. https://doi.org/10.28918/jei.v2i2.1668.

Ni'am, S. (2020). The Debate of Orthodox Sufism And Philosophical Sufism The Study of Maqāmāt in the Sirāj al-Ṭālibīn of Shaykh Iḥsān Jampes. Al-Jami'ah: Journal of Islamic Studies, 58(1), 1-34. https://doi.org/10.14421/ajis.2020.581.1-34.

Nugroho, P. (2017). Internalisasi Nilai-Nilai Karakter dan Kepribadian Mahasiswa Pendidikan Agama Islam Melalui Pendekatan Humanis-Religius. Edukasia : Jurnal Penelitian Pendidikan Islam, 12(2), 355. https://doi.org/10.21043/edukasia.v12i2.2491.

Palmer, A. (2018). The Ring Analogy According to al-Hakīm al-Tirmidhī and Its Implications for Understanding walāya in Ibn 'Arabī' s Fuṣūṣ al-ḥikam. Die Welt Des Islams, 7, 27-46. https://doi.org/10.1163/22105956-12341306.

Rawwas, M. (1988). Dirasah Tahliliyyah Li Syahshiyati Ar-Rasul Muhammad (pp. 1-303). Kairo: Dar An-Nafais.

Sajadi, D. (2019). Pendidikan Karakter dalam Perspektif Islam. Tahdzib Al-Akhlaq: Jurnal Pendidikan Islam, 2(2), 16-34. https://doi.org/10.34005/tahdzib.v2i2.510.

Saramifar, Y. (2018). Crafting Sacrality from the Tensile Life of Objects : Learning about the Material Life of Prayer Beads from a Khaksari Sufi Murshid. Contemporary Islam, 12, 39-55. https://doi.org/10.1007/s11562-017-0407-5.

Tight, M. (2021). Globalization and Internationalization as Frameworks for Higher Education Research. Research Papers in Education, 36(1), 52-74. https://doi.org/10.1080/02671522.2019.1633560.

Weldon, P. A., Rexhepi, J., Chang, C. W., Jones, L., Layton, L. A., Liu, A., Mckibben, S., Misiaszek, G., Olmos, L., Quon, A., \& Torres, C. A. (2011). Globalization and Higher Education in Southern California: Views from the professoriate. Compare, 41(1), 524. https://doi.org/10.1080/03057925.2010.532360. 
Yusuf, M. (2002). Mafhum At-Tashawwuf wa Anwa'uhu fi Al-Mizan As-Syar'i. Giza: Majallah Al-Jamiah Al-Islamiyyah.

Zulfa, U. (2018). Model of Islamic Religion Education 435 Based on Islam Nusantara on College. Nadwa Jurnal Pendidikan Islam, 12(1), 1-12. https://doi.org/10.21580/nw.2018.12.1.2462. 